\title{
Descartes Felsefesinde Kozmolojik Argüman Soruşturması
}

\section{Hasan ÖZALP*}

\section{Cosmological Aroument \\ Investigation in Descartes' Philosophy}

Citation/@: Özalp, Hasan, (2014). Cosmological Argument Investigation in Descartes' Philosophy, Milel ve Nihal, 11 (2), 139-161.

Abstract: One of the important questions in philosophy and theology is proofs of God's existence. Therefore, it is unimaginable that Descartes would be indifferent to the idea of God. In this work, we followed the proposition that "if there is a connection from God to nature, then there should be a connection from nature to God in the same way", and investigated the cosmological evidence in Descartes' philosophy. As a result, we found that comprises different forms of the cosmological argument at Descartes' thought. Descartes utilizes such types of evidencing as first cause, prime mover and ordered teleological argument in particular.

Key Words: Descartes' Philosophy, Argument for Existence of God, Cosmological Argument, Prime Mover, First Cause, Teleological Argument.

Atıf/@: Özalp, Hasan, (2014). Descartes Felsefesinde Kozmolojik Argüman Soruşturması, Milel ve Nihal, 11 (2), 139-161.

Öz: Felsefe ve teolojinin önemli problemlerinden biri Tanrı'nın varlığına dair delillerdir. Bu sebeple Descartes'ın Tanrı düşüncesine ilgisiz kalması düşünülemez. Descartes felsefesinde ise Tanrı genel olarak ontolojik delil ile

* Yard. Doç. Dr., Cumhuriyet Üniversitesi, İlahiyat Fakültesi, Din Felsefesi Anabilim Dalı [ozalphasan66@gmail.com] 
ispatlanır. Biz bu çalışmada "şayet Tanrı'dan doğaya bir geçiş varsa aynı şekilde doğadan da Tanrı'ya bir geçiş olmalıdır" önermesinden hareketle Descartes felsefesinde kozmolojik delili araştırdık. Neticede Descartes'ın kozmolojik argümanın farklı formlarına yer verdiğini de tespit ettik. Descartes özellikle ilk sebep, ilk hareket ettirici ve düzensel teleolojik argüman gibi delillendirme türlerine yer vermektedir.

Anahtar Kelimeler: Descartes Felsefesi, Tanrı'nın Varı̆̆ının Delili, Kozmolojik Argüman, İlk Hareket Ettirici, İlk sebep, Teleolojik Argüman.

\section{Giriş}

Yeniçağın kurucusu ve modern düşüncenin babası kabul edilen René Descartes (1596-1650) bir sistem filozofudur. Bu sebeple onun felsefesinde ontoloji, kozmoloji ve teoloji iç içedir. Ancak salt teolojik bir doktrin olarak Descartes genellikle ontolojik delil ile fazlaca ilişkilendirilir. Bu tamamen doğru bir yaklaşımdır. Descartes, Tanrı'yı zihinsel bir çıkarım türü olan ontolojik argüman ile ispatlamaya çalışır. Filozofun temel paradigmasının da bu yönde olduğu yadsınamaz. Descartes'ın kozmik sistem inşası ontolojik argüman olarak da bilinen Tanrı'dan doğaya doğru bir geçiştir. Filozofun en temel iddiası ve Tanrı'yı ispatlama yolu budur. Ancak bu çalışmalarda genellikle Descartes'ın kozmolojik delile bakışı ihmal edilir. Filozofun kozmoloji görüşü genellikle başlı başına bir problem olan kartezyen ${ }^{1}$ felsefesi bağlamında ele alınır. Bu düşünce de üç tözden biri olan Tanrı, yaratılmamış bir cevher olarak kozmik sistemin d1şındadır. Tanrı her ne kadar yaratılmamış olarak kozmik sistemin dışında olsa da $\mathrm{O}$ bir yaratıcıdır. Bu sebeple kozmos ve Tanrı arasında bir bağıntının olduğu aşikârdır. Fakat Descartes'ın başka ispatlama türleri kullandığ 1 da bilinmektedir. ${ }^{2}$ Ancak bizim burada iddiamız; "şayet Tanrı'dan doğaya geçilebiliyorsa doğadan da Tanrı'ya bir geçiş olmalıdır" şeklindedir. Descartes felsefesi incelenirken bu düşünce genelde pek fazla ele alınmaz. Oysa Descartes gerek Meditassyonlar'da gerekse Felsefenin Illkeleri'nde bu konuya sıklıkla yer vermektedir. Özellikle üçüncü meditasyonda sebeplilik bağlamında konuyu ele almaktadır. ${ }^{3}$ Biz bu çalışmada ontolojik de-

1 Kartezyen ifadesi René Descartes'ın Latince okunuşudur. Filozofun ismi Latince de Renatus Cartesius olarak okunmaktadır.

2 Bkz. Torrey Wang, "Descartes' Three Proofs of God's Existence", Intro to Philosophy, Spring 2012, s. 1-4.

3 Garry Hatfield, Descartes And Meditations, Routledge Philosophy Guide Books, 2003, s. 214. 
lil inşaacısı ve savunucusu olan Descartes'ın kozmolojisini, kozmolojik delille Tanrı'yı ispatlamasını ve Tanrı'nın doğası ve sıfatları ile ilgili görüşlerini inceleyeceğiz.

\section{Tanrı-Doğa İlişkisinin Epistemolojik Diyalektiği}

Tanrı, evrenin var edicisi olduğuna göre bu ikisi arasında bir ilişki kurmak gerekir. Çünkü Descartes'a göre her şey karşılıklı bir ilişki içesinde sistematik bir bütünlüğe sahiptir. Bu sebeple sistemin doğasında olduğu veçhile bir şeyi diğerinden soyutlayarak ele almak yerine tüm sistemi birbirinin mütemmimi olacak şekilde ele almak gerekir. Descartes bu yaklaşımını en iyi şekilde bilgi ağacı metaforunda ortaya koymaktadır. Buna göre felsefeyi bir ağaç olarak ele alacak olursak kökleri metafizik, gövdesi fizik ve bu gövdeden çıkan dallar ise tıp, mekanik ve ahlak gibi bilimlerdir. ${ }^{4}$ Bu sebeple nasıl ki kozmolojiyi ontolojiden bağımsız olarak ele alamıyorsak ontolojiyi de kozmolojiden ayrı düşünmek doğru değildir. Fakat kartezyen felsefesinde Tanrı ve doğanın birbirinden ayrı birer töz olduğu açıkça bilinmektedir. Çünkü yaratılmamış bir töz olarak doğanın d1şındadır ve doğadan Tanrı'dan bağımsız bir tözdür. Şu halde Descartes'ın önünde Tanrı ve evreni nasıl ilişkilendireceğine dair bir sorun çıkmaktadır. Şüphesiz bu sorun bizi Descartes felsefesinin omurgasını oluşturan yöntem sorununa götürmektedir.

Sorunu pedagojik olarak somuttan soyuta doğru ele alacak olursak şüphesiz incelememiz gereken ilk yöntem bilginin deney ve gözleme dayalı olarak elde edileceğini kabul eden empirizmdir. Deney ve gözleme dayalı olduğu için empirizmin temelini şüphesiz duyular oluşturur. İronik bir şekilde doğayı Tanrı'dan ayrı bir töz kabul etmesinden dolayı modern empirik bilimin öncüsü olan Descartes doğayla ilişkilerinde duyulara güvenmemektedir. Çünkü duyular bizi her zaman yanıltabilir. Descartes'a göre Örneğin güneş ile ilgili bilgimizin oluşmasının iki kaynağı vardır. Bu iki kaynak bize birbirinden tamamen ayrı güneş fikri sunmaktadır. Bu kaynaklardan ilki dışsal bir kaynak olan duyularımızdır. Bu duyular bize güneşi çok küçük bir cisim olarak göstermektedir. ${ }^{5}$ Biz güneşi her

4 René Descartes, Principle of Philosophy, Philosophical Writings of Descartes, Trans. John Cottingham, Robert Stoothoff, Dugald Murdoch, Vol. 1, Cambridge University Press, 1985, s. 186.

5 René Descartes, Meditations on First Philosophy, Philosophical Writings of Descartes, Trans. John Cottingham, Robert Stoothoff, Dugald Murdoch, Vol. II, Cambridge University Press, 1995, s. 27; The Search Truth by Means of The Natural Light, 
ne kadar açık bir şekilde görsek de onun bu büyüklük de olduğunu iddia edemeyiz. ${ }^{6}$ Güneş ile ilgili diğer bilgi kaynağımız ise bizimle doğmuş olan ve bazı kavramlardan elde edilmiş içsel hareket noktamızdır. Filozofa göre, bu iki güneş tasavvurunun birbirinin aynı olması mümkün değildir. Bu görüşlerden biri yanlış görünmektedir. ${ }^{7}$

Descartes açık bir şekilde duyu verileri ile akıl verilerinin bir biriyle çatışabileceğini kabul etmektedir. Örnek olması bağlamında güneş ile ilgili bilgilerimize kaynaklık eden duyu ve aklı örnek vermektedir. Buna göre duyular yanılmakta ancak akılla inşa ettiğimiz astronomi doğru bilgiler vermektedir. Descartes güneş örneğini çok basit bir düzlemde ele almaktadır. Bu örnek uzaklaştıkça küçülen tüm eşyalar için verilebilir. Örneğin bir dağ da uzaktan küçük görünebilir. Oysa Descartes'ın çağdaşı olan Galilei Galileo (1564-1642) Descartes'ın tam aksine güneşe yönelik araştırmalarını daha da derinleştirerek salt akılla inşa edilen Aristoteles (MÖ. 384-322) ve Batlamyus (ö. 168) astronomisini teleskop ile yaptığı gözlemler ile yıkmiştır. Bu sebeple aklın ve duyuların her zaman farklı düşünceler ortaya koyarak çelişeceğine dair genel geçer bir ilkeye varmak doğru makul görünmemektedir. Bu sebeple Descartes fazla şüpheci ve spekülatiftir.

Descartes'ın böyle bir yargıya varmasının nedeni ise kendisinden sonra gelen David Hume (1711-1776)'un tümevarıma yönelik eleştirisi ile benzerlik göstermektedir. Hume'a göre tümevarımın tüm eşyaya ve zamanlara teşmil edilmesi mantıksal ve psikolojik bir yanılsamayd $1 .{ }^{8}$ Bilgide ilerlemenin yolunun deneysel araştırmalar olduğuna vurgu yapmasına rağmen ${ }^{9}$ Descartes, deneyler yoluyla olsa da sonuçlardan nedenlere gitmeyi ilke olarak kabul eden tümdengelimi (deduction) doğru bir yöntem olarak görür. Çünkü yeterince denenmemiş olaylara ait sonuçlar bizi aldatabilir. Oysa dünyada var olmuş veya var olabilecek genel ilkeler ve bu ilkelerin

Philosophical Writings of Descartes, Trans. John Cottingham, Robert Stoothoff, Dugald Murdoch, Vol. II, Cambridge University Press, 1995, s. 407.

6 René Descartes, Metot Üzerine Konuşma, Çev. K. Kahir Sel, Sosyal yay., 2. Bsk., İstanbul 1984, s. 39.

7 René Descartes, Meditations on First Philosophy, s. 27.

8 David Hume, An Enquiry Concerning the Human Understanding, Oxford, Clarendon Press, 1895, s. 33-34 vd.

9 René Descartes, Metot Üzerine Konuşma, s. 58. 
nedenlerini tespit ederek araştırma yapmak bizi daha sağlam bir bilgiye götürebilir. ${ }^{10}$ Buradan hareketle Descartes'ın tümevarıma yönelik yöntemsel eleştirilerinin Hume'un eleştirilerine öncülük ettiğini söyleyebiliriz.

Tümevarıma yönelik eleştirisine rağmen Descartes, birçok yerde duyuların bilgimize kaynaklık ettiğini de vurgulamaktadır. ${ }^{11}$ Hatta bizim fayda ve zarara yönelik bilgilerimizin kaynağının duyular olduğunu ifade eder. ${ }^{12} \mathrm{O}$ halde duyuları dışlamasının makul bir gerekçesi olmalıdır. Anlaşılan o dur ki filozofun sorunu duyuların bilgiye kaynaklık edip etmeyeceği değil bunlara güvenilip güvenilmeyeceğidir. Descartes'ı duyular hakkında şüpheye götüren şey sadece bilgi felsefesine uyguladığı şüpheci yöntemdir. Ona göre duyularımız bizi birçok kez aldatmıştır ancak sadece bir defa bile aldatmış olsa yine de duyularımıza asla güvenemeyiz. ${ }^{13}$ Descartes epistemolojiden hareketle ontolojiyi temellendirmeye çalışmasından dolayı şüpheyi sadece duyulara ve dolayısıyla epistemolojiye tahsis etmektedir. ${ }^{14}$ Bu yaklaşım iki açıdan sorunlu görünmektedir. Şöyle ki Descartes'a göre hayatımızın sevk ve idaresi ile ilgili şeylerde kesinlikle şüpheye düşülmemeli varsa da şüpheden derhal kurtulmalıdır. Zira bir delili diğerlerinden doğruya daha yakın olduğunu bilmesek bile işi geciktirmekten ziyade seçtikten sonra sebat göstermek ve kararlı olmak aklın bir gereğidir. ${ }^{15}$ Yani Descartes pratik yaşam açısından felsefeyi ele almamaktadır. İkinci sorun ise, Descartes'ın duyulara yönelttiği şüphesini akla yönelttiğimiz zaman ortaya çıkmaktadır. Descartes duyuların bizi çoğu kez yanılttığını ancak sadece bir defa bile yanıltmış olsa bile onlara güvenilemeyeceğini ifade etmekteydi. Aynı durum akıl yoluyla elde ettiğimiz bilgiler içinde geçerlidir. Aklın bizi birçok kez yanılttığını hiç olmazsa bir defa yanılttığına tanıklık etmişizdir. Bu durum duyular ve akılla ilgili edindiğimiz bilgilere kuşkulu yaklaşmamız gerektiğini gösterir ancak bizi mutlak bir şüpheciliğe götürmemelidir.

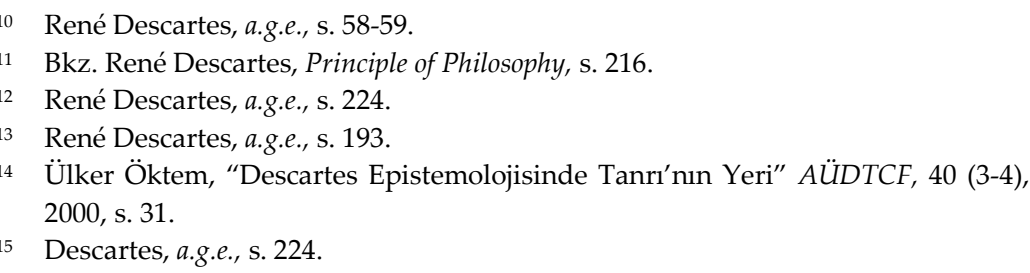


Oysa Descartes şüpheyi bir araç olmaktan ziyade amaç haline dönüştürmektedir. Neticede filozofa göre Tanrı ve ruh konusuna dair fikirler hiçbir zaman duyularla ispatlanamaz. Bu sebeple 'duyuda bulunmayan şeylerin zihinde yeri yoktur' şeklinde ki bir düşünce yanlıştır. ${ }^{16}$

Descartes'a göre tıpkı duyulara güvenemediğimiz gibi hayal gücüne de güvenmemiz mümkün değildir. Keçi gövdesi üzerine oturtulmuş bir aslan başını açık bir şekilde tahayyül etsek de akıl bunun mümkün olmadığına bizi ikna edecektir. ${ }^{17} \mathrm{Bu}$ sebeple filozof kendi ifadesiyle "ne duyuların değişen şahitliğine ne de muhayyilenin aldatıcı hükmüne" güvenmemektedir. ${ }^{18}$

Descartes'ın Tanrı ve kozmos ilişkini yapılandırmaya çalıştığı ikinci yöntem zihinden hareketle oluşturulan ve aklın kullanılmasını zorunlu kılan rasyonel yaklaşımdır. Descartes açık bir şekilde aklı merkeze alarak düşüncesini inşa eder. Burada ele alınması gereken sorun filozofun bunu nasıl temellendirdiğidir. Descartes'a göre ben nedir? sorusunun cevabı düşünen bir şey olmamızda yatmaktadır. Bu yaklaşımıyla Descartes, insan tanımına yönelik klasik yaklaşımı ortaya koymaktadır. Bu yaklaşımın temeli ise İbn Sina (980-1037)'nın boşluktaki insan fikrini çağrıştırmaktadır. ${ }^{19}$ Şöyle ki bir insan düşünüyorsa bu onun şüphe ettiğini, anladığını, kavrad1ğını, tasdik veya reddettiğini ve tahayyül ettiğini gösterir. Peki, insan bunları dışsal bir güç olarak mı ortaya kor yoksa bu güçler içsel midir? ${ }^{20}$ Bunu ispatlamanın yolu imkânsız gibi görünse de tüm duyulardan ve dolayısıyla dış dünyadan soyutlayarak insanın kendisini düşünmesidir. Bu ameliye sonucu görecek ki duyması, anlaması, tasdik veya reddetmesi tamamen kendisinden kaynaklanan bir şeydir. ${ }^{21}$ Şu halde insanın kendinde var olduğundan şüphe edemeyeceği bir akıl vardır. Peki, bu aklın ürettiği bilgiler ne ölçüde doğru ve kalıcıdır. Descartes konuyu bir balmumu örneği üzerinde

16
Descartes, Metot Üzerine Konuşma, s. 37.

Descartes, a.g.e., s. 39.

René Descartes, "Rules for the Direction of the Mind", Philosophical Writings of Descartes, Trans. John Cottingham, Robert Stoothoff, Dugald Murdoch, Vol. 1, Cambridge University Press, 1985, s. 14.

İbn Sina ve Descartes'ın Meditationsında benzer birçok paralel noktanın olduğu araştırmacılar tarafından da teyit edilmiştir. Konumuzla ilgili olarak bkz. H. Ömer Özden, İbn Sina-Descartes (Metafizik Bir Karşılaştırma), Dergah yay., İstanbul, 2000, s. 197-217.

Descartes, Meditations, s. 19.

Descartes, a.g.e., s. 17. 
açıklar. Bir balmumunu ateşe yaklaştırdığımız zaman, tadı kaçıyor, kokusu gidiyor, rengi değişiyor, şekli kayboluyor, ona dokunmak güçleşiyor, ona vurulsa da ses çıkarmıyor. Balmumu yakıldığı zaman değişen şeyler dil, burun, göz, kulak ve dokunma duyularının elde ettiği verilere yönelik değişimlerdir. Bu durumda filozof bu değişmelerden sonra balmumunun aynı kalıp kalmadığını sorar. Descartes'a göre balmumu aynı kalmaktadır. Çünkü görüldüğü gibi biz hala bir balmumu üzerinde konuşmaktayız. Onda bu kalıcılığı sağlayan şey duyular vasıtasıyla elde ettiğimiz bilgiler değildir. Çünkü tatma, koklama, işitme, görme ve dokunma yoluyla elde etiğimiz şeyler tamamen kaybolmuştur. Ancak yine de ortada bir balmumu vardır. Çünkü balmumu ne bal lezzeti ne çiçek kokusu nede sesti o sadece bir cisimdi ve şimdide öyledir. Balmumuna ait tek gerçeklik ve değişmeyen şey bizim onu kavradığımız şeydir. ${ }^{22}$ Şu halde tüm değişimlere rağmen duyuların değil aklın kaynaklık ettiği bilgiler kalıcı olmuştur.

Sonuç olarak elimizde üç gerçeklik kalmıştır. Birincisi, kendisine güvenmeyeceğimiz duyular, ikincisi, bize ait bir gerçeklik olması bakımından kesin bilgi veren akıl ve üçüncüsü, kuşku duyduğum duyularla müşahede ettiğim evren. Şu halde biz nasıl kozmosdan Tanrı düşüncesine ulaşacağız?

\section{Kozmolojik Delil Soruşturması}

Duyulara güvenmeyen Descartes, skolastik hocalarından kurtulduktan sonra gerçeği kendi zihninde ve büyük dünya kitabında aramaya karar verdiğini belirtir. ${ }^{23}$ Kozmos ve kozmosa ait canlılar, yıldızlar ve diğer nesneler birer gerçekliktir. ${ }^{24}$ Peki, bu gerçeklik nasıl meydana gelmiştir?

Kozmolojik delilin, doğanın farklı noktalarına referanslarda bulunan birçok çeşidinin olduğu bilinmektedir. Bu noktada Descartes "her nedenlinin bir nedeni (fail) ve başlangıcı olan her şeyin bir sebebi (fail) vardır" şeklindeki Aristotelesçi klasik formu kullanır. $\mathrm{Bu}$ da her ne kadar skolastik düşünceden koptuğunu iddia etse de

\footnotetext{
Descartes, a.g., s. 20-21.

Descartes, Metot Üzerine Konuşma, s. 14.

Descartes, a.g.e., s. 37.
} 
Descartes'ın bunu özellikle metafizik de tam olarak gerçekleştiremediğinin bir göstergesidir. İmdi bu düşüncenin temellerini ele alalim:

Nedensellik Aristoteles'in düşünceye kattığı ve Antik dönemlerden çağımıza kadar aktüealitesini koruyan bir sorun(n)dur. Aristoteles felsefesinde araştırmaya konu olan maddi neden, formel neden, fail neden ve ereksel neden olmak üzere dört neden vardır. ${ }^{25}$ İmdi maddi ve formel neden içsel nedenler iken fail ve ereksel nedenler dışsal nedenlerdir. Biz varlığı bu nedenler ile açıklayabiliriz. Fail neden hem maddeyi var edip şekil vermekte hem de ona bir amaç tayin etmektedir. Şayet fail olmazsa diğer nedenleri açıklayamayız. Bu sebeple her nedenlinin bir nedeni vardır.

Descartes'a göre yokluğun bir şey meydana getirmesi mümkün değildir. Bu sebeple doğada ki gözlemlerimizden anlaşılmaktadır ki bir ürün ya da eser ortaya koyan nedene fail neden denmektedir. Aynı zamanda bir düşünce ya da ide gerçekliği kendi dışından değil de kendinden alıyorsa buna formel neden denilir. Ancak bu nedenler dünyasında bir tamam ve yeter sebep aranmalıdır. Her ne kadar bir şeyin mutlaka bir nedeninin olduğunu kabul etsek bile bunu sonsuza kadar götüremeyiz. Bu sebeple bir yerde durup eşyaya ait gerçekliği açıklamak için bir yeter neden göstermemiz gerekir. Michelangelo'nun Davut heykelini epistemolojik olarak çözümlemek istiyorsak bunun kim tarafından, hangi maddeden, ne surette ve niçin yapıldığının açıklanması gerekir. Descartes bizim kozmolojik argüman olarak ifade ettiğimiz Tanrı, madde ve sebep ilişkisini iki şekilde temellendirir.

\section{a. I. Kozmolojik Argüman: Hareketin İlk Kaynağı Olarak İlk Mu- harrik}

Bu argüman evrensel hareketin nedenine yönelik bir çıkarımdır. İlk hareket ettirici düşüncesini ortaya atan düşünür şüphesiz Aristoteles'dir. Daha sonra ise bu delili Farabi (870-950) ve İbn Sina gibi İslam Meşşâi filozofları kullanmış ve son olarak skolastik gelenek de Thomas Aquinas (1225-1274)'un beş ispat yolundan biri olmuştur.

Aristoteles felsefesinde evrenin oluş ve işleyişinin kaynağını açıklamak için ileri sürülen bu delil fizikten metafiziğe geçişin temel

25 Aristoteles, Fizik, 194b-15 vd., Çev. Saffet Babür, İstanbul YKY yay., 2001, s.61 vd.; Aristoteles, Metafizik, 325a-25, çev. Ahmet Arslan, Sosyal yayınları, 1996, s. 86. 
postülatını oluşturmaktadır. "Hareket Etmeyen Ilk Hareket Ettirici" olarak ifade edilen yeter sebep Aristoteles düşüncesinde fiziksel nedenselliği aşan nihai metafiziksel bir fail neden olarak tanımlanmaktadır. Bu da bize fiziğin metafiziğe nasıl bağlandığını göstermektedir. Aristoteles'e göre maddenin olduğu yerde zorunluluk ve hareket vardır. Evrenin oluşumunu bu bağlamda zorunluluk kavramı ile açılayan Aristoteles'e göre mutlak, doğal ve şartlı olmak üzere üç tür zorunluluk vardır. a) Mutlak zorunluluk, ezeli varlıklarda rastlanan türdür. b) Doğal ve basit zorunluluk, sanatsal olaylarda ve doğal olayların tamamında rastlanır. "Sen varsan baban da vardır." gibi. c) Şartlı zorunluluk, formun meydana gelmesi için maddenin var olması gerektiği şeklindeki zorunluluktur. ${ }^{26}$ Aristoteles ve takipçilerini böyle bir düşünceye sevk eden amil ise varlıkların formları ve evrenin amaçsal varoluşudur. ${ }^{27}$ Madde ezeli olmasina rağmen yetkinleşememiştir. Bu sebeple yetkinleşmek için harekete ihtiyaç duyar. Hareketin kaynağ 1 ise kendisi olsa bile bunu sonsuza kadar götürmek imkânsız. Çünkü hareket halinde ki şey yetkinleşememiştir. Bu sebeple yetkinleşemeye bir kaynak bulmamız gerekiyorsa hareket etmeyen bir hareket ettiriciyi kabul etmemiz gerekir. Bu da maddenin dışında bir gerçeklik olmalıdır. Bu sebeple İlk sebep diyebileceğimiz varlık hareket etmeyen ilk hareket ettiricidir. Bunun neticesi olarak Aristoteles evreni mekanik olarak tasavvur etmektedir ve dolayısıyla deisttir. ${ }^{28}$

Descartes'a göre hareket, maddenin bir kısmının veya bir cismin doğrudan doğruya temasta olduğu ve durağan farz ettiğimiz cisimlerin yanından diğer cisimlerin yanına geçmesidir. Bu bağlamda bir cisim ya da maddenin bir kısmında toplu olarak geçen bütün şeylerdir. ${ }^{29}$ Hareketin ne olduğuna yönelik bir soruşturma fiziğin problemidir. Felsefi açıdan asıl problem hareketin nedeninin/kaynağının ne olduğudur. Evrende hareketliliğe kaynaklık eden farklı hiyerarşilerde nedenlerin olduğu aşikârdır. Peki, dünyadaki tüm hareketleri meydana getiren ilk ve tümel neden nedir? Bu sorunun en açık ve kesin cevabı Tanrı'dır. Descartes bunu şöyle temellendirir:

Aristoteles, Fizik, s. 91-92.

Bkz. Aristoteles, Fizik, s.61 vd.; Aristoteles, Metafizik, s. 236.

Eduard Zeller, Grek Felsefesi Tarihi, Çev. Ahmet Aydoğan, İz yay., İstanbul, 2001, s. 220-221.

29 René Descartes, Principle of Philosophy, s. 233. 
Tanrı büyük gücü ile maddeyi hareket ve sükûnetle birlikte yaratırken evrene koyduğu aynı hareket ve sükûneti muhafaza eder. Zira her ne kadar hareket, hareket eden maddenin bölümlerinden bazılarında bazen az, bazen çok bulunsa da, bununla beraber onda hiçbir zaman azalıp çoğalmayan belli bir hareket miktarı vardır. ...Ve gene yalnız değişmez bir öze sahip olmak değil, fakat daima değişmez bir tarzda hareket etmeninde Tanrı'nın olgunluğundan olduğunu da biliyoruz. O derece ki, dünyada gördüğümüz ve Tanrı tarafından vahiy ile bildirildiği için, inandığımız ve yaratıcıda hiçbir değişme olmaksızın tabiatta vukua geldiğini veya gelmiş olduğunu bildiğimiz değişmelerden fazla olarak, eserlerinde, ona kararsızlık atfetmek korkusuyla, başkalarını farz etmemeliyiz. Böylece mademki, yarattığı zaman, maddenin bölümlerini birçok çeşitli tarzda harekete geçirmiştir ve gene onların hepsini aynı tarzda ve yarattığ zaman tabi kıldığı aynı kanunları devam ettirmektedir, öyle ise bu maddede eşit (veya sabit) miktarını durmadan muhafaza etmektedir. ${ }^{30}$

Bu bağlamda Descartes'ın fiziksel dünyanın hareketliliğinden Tanrı düşüncesine ulaşmasının bazı argümanlarını görmekteyiz. Öncelikle hareketin doğası ve eşyada ki ritmi buna işarettir. Şöyle ki her ne kadar maddenin bazı bölümleri az bazı bölümleri çok hareket etse de onda hiçbir zaman azalıp çoğalmayan bir hareket miktarı vardır. Bu değişmeyen miktar bizi iki tür çıkarıma sevk etmektedir. Birincisi hareketin istikrarlı olması bizi istikrarın kaynağına götürmektedir. İkincisi ise istikrarın devamıdır. Bu iki düşüncenin kesim noktası değişmezliktir. Değişmez olan ise bizi değişmez bir öze sahip olan Tanrı fikrine ulaştırır. Bu bir mükemmellik göstergesidir.

İkincisi, Tanrı hareketin kaynağı olması bakımından değişiminde nedenidir. Fakat değişimin nedeni olması bizi onda da bir değişim olduğu şeklinde yanlış bir sanıya götürmemelidir. Kendisinde değişim olacağı kaygısıyla Tanrı' yı hareketin kaynağı olarak görmekten uzak durmamalıyı. Zira var ettiyse varlığın devamını da sağlamaktadır.

Üçüncüsü ise, ikinci maddenin tamamlayıcısıdır. Descartes'ın birçok yerde dile getirdiği gibi doğa yasalarının devamı ve istikrarına yönelik güvencemizin nedeni Tanrı'dır. ${ }^{31}$ Bu sebeple Descartes

\footnotetext{
30 Descartes, a.g.e., s. 240.

31 Bkz. Descartes, Metot Üzerine Konuşma, s. 40.
} 
bunu bir ilke olarak görür. Filozofa göre, doğanın birinci kanunu, her şey başka bir şey onu değiştirmedikçe bulunduğu durumda kalır. ${ }^{32}$ Newton' un birinci yasasına benzer nitelikte olan bu değişmezlik ilkesi doğa bilimlerinin ivme kazanmasında katalizör görevi üstlenmiştir. Çünkü yer kürenin bir yerde çekip başka bir yerde çekmemesi gibi doğa yasaları farklı yer ve zamanlarda farklı davransalardı bilimlerde ilerleme mümkün olmazdı. Bu durum aynı zamanda bizi doğadan Tanrı'ya götüren diğer bir argümandır. Çünkü insan yaşamının devamı da buna bağlıdır. Su her zaman boğar ve ateş her zaman yakar. Descartes'ın bu düşüncesi çağdaşı ve devamı olması bağlamında Baruch Spinoza (1632-1677)'yı da etkilemiştir. Spinoza'da Tanrı'nın başta yasaları yaratıp sonra bunlara aykırı davranmasını akıl dışı kabul etmekte ve aksi durumda Tanrı'nın kendisiyle çelişeceğini iddia etmektedir. ${ }^{33}$

Descrates'ın Tanrı'yı ilk hareket ettirici olarak görmesi Aristoteles düşüncesi ile benzerlikler göstermektedir. Neticede Descartes tıpkı Aristoteles'de olduğu gibi doğa yasalarını Tanrı ile güvence altına alarak maddeyi Tanrı'dan bağımsız bir töz haline dönüştürerek Aristoteles'in mekanik evren anlayışına varmakta ve dolayısıyla deistik Tanrı tasavvurunda durmaktadır. ${ }^{34}$ Bu yöntem ile Descartes'ın özgün olduğunu iddia etmek zor görünmektedir.

\section{b- II. Argüman: Kozmosu var eden İlk Sebep}

Descartes, gözlemlerimiz sonucunda doğa yasalarının edilgen olduklarını ve kendilerine etki eden bir failin olduğunu düşünmektedir. ${ }^{35}$ Pe ki failin ne olduğunu ve doğasını nasıl belirleyebiliriz? Filozofa göre, maddi dünyayı incelediğimizde bunlara ait cevher, süre ve benzer nitelikler görmekteyiz. Örneğin taşın kendi başına bir cevher ya da kendiliğinden var olmaya başka bir ifadeyle kendini var etmeye gücü yeten bir şey olduğunu varsayalım. Aynı şekilde bir birey ve canlı olarak kendimizin de benzer vasıflara sahip olduğunu düşünelim. Birey olarak ben ve taş arasında benzer olmayan birçok nitelikler bulunsa da son tahlilde ikisi de cevher olma noktasında aynıdır. İmdi ya her bir şey kedinin nedeni ya da birisi diğerlerinin nedenidir. Bu iki cevher arasında kendimi fail olarak varsaydığım

32 Descartes, Principle of Philosophy, s. 241-242.

33 Nancey Murphy, "Bilim, İlahi ve Zeki Tasarım Akımı: Teistik Evrimciliğin Bir Savunusu", Evrim ve Tasarım (Gelen-Eksel ve Çă̆daş Metinler Seçkisi), Der. R. Alpyağıll, İz yay., İstanbul, 2013, s. 534.

34 Ahmet Cevizci, On Yedinci Yüzyll Felsefesi Tarihi, ASA yay., Bursa, 2007, s. 140.

35 Descartes, Meditations, s. 28. 
zaman kendimde maddeye ait nitelikler olan uzam, şekil, durum, hareket gibi başka vasıfları formel olarak görmemekteyim. Oysa düşünen bir cevher olarak bende bahsi geçen bu vasıfların bulunması gerekir. Çünkü ben düşünmek bakımında üstün bir cevherim. Bu sebeple maddi dünyada üstün bir cevher olarak bende bu vasıflar yoksa bu dünyayı açıklayacak fail Tanrı' dır. ${ }^{36}$ Bu bağlamda Descartes'ın kozmolojik argümanını şu şekilde formüle edebiliriz:

Öncül 1: Her nedenlinin bir nedeni vardır.

Öncül II: Bu nedenler sonsuza götürülemez. Bir nedende durmak gerekir.

Öncül III: Neden arayışını maddi dünyada sürdürebiliriz.

Öncül IV: Maddi dünyada ki en muhtemel neden düşünen dolayısıyla en yetkin varlık olan insan olabilir.

Öncül V: İnsanda maddi dünyayı oluşturacak tüm formlar bulunmamaktadır.

Sonuç: Öyle ise maddi dünyadaki her şeye etki eden neden Tanri'dır.

Descartes'ın bu yaklaşımı klasik kozmolojik çıarımdır. Maddi nedenler dünyasında mükemmel neden bulunmaması fikri bu düşüncenin odak noktasını oluşturmaktadır. Delilin ikinci belki de en önemli kısmı Descartes'a özgü olan kozmolojik delinin ontolojik delile bağlamasıdır. Bu iki sorun daha sonra hem Hume hem de onun dogmatik uykusundan uyandırdığı Immanuel Kant (1724-1804)'ın eleştirilerinin de merkezi olacaktır.

Birinci sorun Descartes'in kozmolojik argümanı nihai olarak ontolojik argümana bağlamasıdır. Ontolojik-kozmolojik argüman olarak ifade ettiğimiz bu yaklaşıma göre Descartes'ın nihai fail neden olarak Tanrı'ya ulaşmasının nedeni kendi zihninde Tanrı'yı var olan bir gerçeklik olarak görmesi yatmaktadır. Şöyle ki Descartes'a göre bir cevher olarak insanın zihninde sonsuz bir cevher fikrinin bulunmasının nedeni Tanrı'dır. Çünkü Tanrı olmasaydı sonlu bir varlık olan insanda sonsuz bir cevher düşüncesi olmazdı. ${ }^{37}$

Açık bir şekilde Descartes kozmolojiden başladığı düşünceyi ontolojik argümana bağlamaktadır. Aslında salt kozmolojinin sınırları dahilinde kalması delili daha güçlü kılardı. Bu sebeple bir yanı ontolojik delil ile ilişkili olan kozmolojik argüman Kant'ın ontolojik delile yönelttiği eleştirilere de maruz kalmaktadır. Kant ontolojik argümanı birkaç açıdan eleştirmektedir. Kant’a göre öncelikli sorun

36 Descartes, a.g.e., s. 30-31.

37

Descartes, Meditations, s. 31-32. 
hükümlerin mutlak zorunluluğunun nesnelerin mutlak zorunluluğunu gerekli kıldığı yönündeki yanılgıdır. Yani Descartes'ın zihninde bir Tanrı inşa etmesi gerçekte bir Tanrı olduğu şeklinde anlaşılmamalıdır. ${ }^{38}$ Kant'ın ontolojik argüman eleştirilerini bu bahiste ele almak konumuzun sınırları dişındadır. Bu sebeple sorunu derinleştirmek istemiyoruz.

İkinci sorun, fail nedenin niçin maddi dünyada aranmadığıdır. Descartes'ın cevap verdiği bu eleştiriyi daha sonra Hume "nedenselliğin neden maddi dünyada durmadığını" sorarak problemi güncelleştirecektir. Aslında Descartes buna doğru ama eksik bir cevap vermektedir. Çünkü salt insanın yetkin olmaması yeterli bir cevap değildir. Örneğin Doğa Bilimcisi Charles Darwin (1809-1882) canl1lığın doğal seleksiyon ve adaptasyon ile kendi kendini organize ettiğini açıklayan güçlü bir teori ileri sürmüştür. Bugün evim olarak ifade ettiğimiz bu teori maddi dünyanın nedeninin yine maddi dünya olduğuna dair güçlü bir rasyonel çıkarımdır.

Muhtemelen Descartes böyle bir eleştirinin farkındadır. Bu sebeple maddi dünyada ki muhtemel fiziksel nedenleri ele alarak birkaç fiziksel nedeni tartışır. Bunlardan ilki anne ve baba fail neden olup olmayacağıdır. Buna göre, organizmanın asli varoluş nedeni ebeveynler midir?

Filozofa göre, anne ve baba dünyaya gelmemizin nedeni olarak görünmektedir. Bununla beraber yine de anne-babamız düşünen bir varlık olarak insanı dünyaya getiren ve yaşamını devam ettiren varlıklar olamaz. Çünkü düşünen bir cevher ile maddi bir eylem arasında hiçbir ilişki yoktur. Oysa anne-baba bizi sadece maddi bir fiille dünyaya getirir. Başka bir ifadeyle ebeveynler sadece maddeye bazı biçimler vermişlerdir. Oysa insan sadece suret almış bir madde olmanın ötesinde ruh sahibi düşünen bir varlıktır. Bu sebeple insanı gerçekte var eden anne ve baba olmayıp onun zihnine kendi varlığını nakşeden Tanrı'dır. ${ }^{39}$

Descartes bu soruşturmayı yine kozmosun sinırları içerisinde kalarak bir kategori daha yükselterek varlığın nedeni veya yaratıcı bir insan olarak ben olabilir miyim? diye sorar. Filozofa göre benim, kendi varlığımın ve diğer tüm var olanların yaratıcısı olmadığımın birçok nedeni vardır. Öncelikle şayet insan bir yaratıcı olsaydı onun

38 Bkz. Mehmet Dağ, “Ontolojik Delil ve Çıkmazları” Ankara Üniversitesi İlahiyat Fakültesi Dergisi, c. XXII, 1978, s. 301.

39

Descartes, Meditations, s. 34. 
hiç bir şeyden kuşku duymaması gerekirdi. Eğer ben, kendimi ve diğer tüm şeyleri yaratmış olsaydım bunların hepsine dair tam bir bilgim olurdu. Oysa insanda öğrenme arzusu ile birlikte derin bir şüphe bulunmaktadır. Bu da yaratıcının insan olmadığını göstermektedir. ${ }^{40}$

İkincisi ise yine birinci nedenin devamı niteliğindedir. Şayet insan (ben) Tanrı olsaydı kendini hiçbir açıdan eksik yaratmazdı. Bu sebeple insanda tam bir mükemmellik olurdu. Oysa düşünen bir birey olarak insan, kendini yokluktan çıkarmadığı gibi hiç değilse edinilmesi kolay olan şeylerden kendini mahrum etmezdi. Ya da kendinde bulmayıp da bugün bana Tanrı vergisi dediği şeyleri kendine verirdi. Oysa bu noktada insan gücünün sona erdiğini sürekli tecrübe etmektedir. ${ }^{41}$

Üçüncüsü, insan hayatının birçok aşaması vardır ve bunlardan biride ölümdür. Şayet insan kendinin yaratıcısı olsaydı kendi hayatını muhafaza eder ve yeniden diriltebilirdi. Oysa cevher denilen şey zamanın tüm dilimlerinde vardır. Bu aşamada Descartes şu soruyu sorar: Acaba şimdi var olan ben gelecekte de var olabilmek için bir kudret ve kabiliyete sahip miyim? Descartes bu soruyu usulden ele alır. Buna göre benim böyle bir düşüncemin olması bile bende bu kudret ve kabiliyetin olmadığının göstergesidir. Ancak yine de açıkça ifade eder ki insan da böyle bir kudret yoktur. Bu sebeple varlığımın sebebi ve devamı benim dışımda bir varlık olan Tanrı' dandır. ${ }^{42}$

Dördüncüsü, insanın kendi duyuları arasında yaptığı bir kıyastır. İnsanda düşünme, hafıza ve muhayyile gibi pek çok yeti bulunmaktadır. Fakat insan kendini gözlemlediği zaman bu duyuların kendinde küçük ve sınırlı ölçüde bulunduğunu görecektir. Oysa böyle yetilerin varlığını kabul ediyorsak bunların Tanrı'da daha geniş ve sonsuz olduğunu kabule etmemiz gerekir. ${ }^{43}$

Beşincisi, Descartes kendisinin Tanrı olmadığı düşüncesini ontolojik argüman ile ortaya koymaktadır. Buna göre eğer insan, zihninde daha yetkin bir varlık taşıyorsa bu kendisinin yaratıcı olmadığı anlamına gelir. Bu konu araştırmamızın dışındadır. ${ }^{44}$

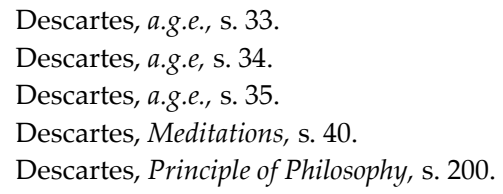


Descartes kozmik dünyada ki neden arayışındaki çıtayı biraz daha yükselterek tüm nedenlerin bir araya gelerek evreni yaratmalarının imkânını sorgular. Buna göre tüm nedenler bir araya gelerek işbirliği etse yani bu sebeplerden birine Tanrı'ya atfettiğimiz bilgiyi, diğerlerine başka sıfatları versek ve netice de hepsinin Tanrı olacak şekilde birleştiklerini varsayalım. Descartes'a göre bu mümkün değildir. Çünkü Tanrı dediğimiz şey basittir. ${ }^{45}$ Yani parçalardan oluşmamaktadır. Şayet Tanrı mürekkep bir varlık olsaydı, bölünürdü ve bir parçası diğer parçasından önce gelirdi. Bu da onun Tanrı olmadığını gösterir. Fakat Descartes'ı klasik nedensellik yoluyla ispatlama düşüncesinden ayıran şey Tanrı'nın sadece müsebbip olarak fail olması değil aynı zamanda varlığı koruyan ve muhafaza eden bir kimliğinin de bulunmasıdır. ${ }^{46}$

Doğanın nedeni olan Tanrı'nın kendi kendisinin illeti olması ise Descartes'a göre mantıksal bir zorunluluktur. Şöyle ki Tanrı'nın varlığı başka bir illetten meydana geliyorsa, aynı sebepten dolayı, bu ikinci illetinde, başkası tarafından mı yoksa kendiliğinde mi var olduğunu tekrar sormak gerekir. "Ta ki nedenler hiyerarşisi derece derece en sonunda Tanrı olacak bir nedene varılsın. Descartes'a göre bu teselsülde sonsuza kadar gitmek mümkün değildir. Çünkü burada tartışmaya konu olan neden beni meydana getiren değil muhafaza eden nedendir. ${ }^{47}$

\section{c. Kozmolojik Düzen ve Telos İlişkisi}

Evrenin bir amaca hizmet ettiği ve dolayısıyla bu amacın Tanrı tarafından tayin edildiğini varsayan teleolojik veya tasarım argümanı da Descartes kozmolojisinde önemli bir yer tutar. Teleolojik argümanının birkaç formu vardır. Bunlardan ilki evrenin düzenine gönderme yaparken diğeri düzenin nihai gerekçesi olan amacı ön plana çıkarır. Kısaca birincisi düzeni (nizam) ikincisi amacı merkeze alır. Descartes kozmolojik delil açısından birincisine kısmi olarak yer verir. Öncelikle evren Tanrı'nın verdiği bir güvence ile istikrarlıdır. Dolayısıyla bizim onda bir düzen ve harmoni aramamız gerekir. Nitekim filozofa göre ayrı ayrı ustaların ellerinden çıkmış kurulu parçalarda tek ustanın kendi başına elinden çıkardığı parçadaki gibi

\footnotetext{
Descartes, Meditations, s. 34.

Descartes, a.g.e., s. 33.

Descartes, a.g.e., s. 32-33.
} 
mükemmellik yoktur. Nitekim bir mimarın tek başına kurduğu yapılar birçok mimarın farklı amaçlarla yapılmış eski duvarlar üzerine kurduğu yapılardan daha düzenlidir. ${ }^{48}$ Şu halde tasarım bizi bir tasarımcıya götürdüğü gibi onunda yetkin olması için tek olması gerekir. Genellikle bina ve mimar analojileri üzerinden yapılan ispatlamalarda benzeyen ve benzetilen ilişkisinin kesin uyumu beklentisinden dolayı Tanrı ve evren ilişkisi deistik bir tarzda açıklanmaktadır. Mimar olarak Tanrı evreni her ne kadar mükemmel bir şekilde var etse de artık işleyişine karışmamaktadır. Descartes felsefesinde evren Tanrı'nın müdahil olmadığı mekanik bir yapıya sahiptir.

Teleolojik argümanın amaca vurgu yapan ikinci formunun temelini Aristoteles'in ereksel nedeni oluşturur. Buna göre eşyanın var oluş amacını tayin eden erek, dört nedenden biridir. Nihayetinde maddenin dişında bir gerçeklik olan ereksel nedeni tayin eden şey fail nedendir. Bu sebeple de ereksel neden fail nedene indirgenebilir. Bu durum da eşyada bir amaç varsa bunu evrensel bağlamda tayin eden kişi Tanrı'dır. Descartes amacı merkeze alan bu tarz bir ispatlama yöntemini kabul etmemektedir. Filozofa göre, felsefi olarak bizim amacımız varlıkların ne tür bir vasita ile meydana geldiklerini incelemektir. Yoksa Tanrı'nın onları ne tür bir amaç için yarattığını bilmek değildir. Bu sebeple araştırmacı, Tanrı'nın dünyayı yaratırken güttüğü amaçları incelemek ve sonlu ereksel nedenleri araştırmakla vakit geçiremez. Çünkü bizim zihin dünyamızın da var edicisi ve her açıdan mükemmel bir varlık olan Tanrı'nın bize maksatlarını bildirmek isteyeceğini sanmak bir yanılsamadır. Bizim amacımız, onun bütün her şeyin yaratıcısı olduğunu göz önüne alarak, duyular vasıtasıyla kavradığımız şeylerin nasıl meydana geldiklerini bize verdiği akıl sayesinde bulmaya çalışmaktır. ${ }^{49}$

Descartes'ın ifade etmeye çalışttı̆ 1 şey bir kısım teolojik okulların kabul ettiği ve toplum arasında yaygın olan "hikmetinden sual edilmez" düşüncesidir. Descartes'ı bu düşünceye sevk eden şey nedir? Bu sorunun halk arasında ki yaygın cevabı, "Tanrı'nın sonsuz ulûhiyetine duyulan saygıdır." Bu daha çok duygusal bir yaklaşımdır. Descartes, düşüncesini bu şekilde temellendirmez. Filozofa göre bir defa böyle bir yaklaşıma şaşmamak gerekir. Bunun duyusal ve rasyonel olmak üzere iki nedeni vardır. Duyusal nedeni, etrafımızı

48 Descartes, Metot Üzerine, s. 15-16.

49 Bkz. Descartes, Principle of Philosophy, s. 202. 
gözlemlediğimizde yani duyusal tecrübelerimizle bizi kuşatan eşyanın birçoğunun Tanrı tarafından neden ve niçin yaratıldıklarını anlayamıyoruz. Bu sebeple de sırf biz anlayamadığımız için Tanrı'nın varlığından kuşku duymamamız gerekir. Peki, "duyusal tecrübelerimiz ile açıklayamadığımız konularda Tanrı'dan niçin kuşku duymamalıyız" şeklinde gelebilecek bir soruya bizce makul cevaplardan biri şuan ki mevcut aklımızın ve bilimin bunları kavramak için yetersiz olduğudur. Oysa Descartes sorunu yine ontolojik delil ile çözmeye götürür. Filozofa göre insan tabiatı son derece aciz ve sınırlı iken Tanrı'nın tabiatı büyük, anlaşılmaz, kavranılmaz ve sonsuzdur. Bu sebeple ilahi amaç (ya da nedenler) zihnimizin anlama gücünü aşan sonsuz ve tükenmez niteliktedir. Neticede gayeden çıkarılan tüm nedenler hiçbir işe yaramaz. ${ }^{50}$ Descartes'ın bu görüşüne katılmadığımızı belirtelim. Çünkü ister Aristoteles felsefesi ile birlikte isterse başka şekilde düşünülsün gâî neden bir anlama ve açıklama türüdür. Aksi takdirde eşya tamamen anlamsızlığa itilmiş olacaktır. Bu anlamsızlığın sorumlusu ise kendisine tüm mükemmellikler verilerek sözde tenzih edilmeye çalışılan Tanrı olacaktır. Bu durumda, "her açıdan mükemmel bir varlık olan Tanrı nasıl oluyor da benim yaşadığım ve etkileşim halinde olduğum bir evrende benim zihnimin kavrayamayacağı şeyleri var ediyor?" Bu durum Tanrı için bir eksiklik olurdu.

\section{Tanrı'nın Doğası ve Sıfatları Üzerine Soruşturma}

Descartes'ın kozmolojik delillendirmesinin temelini ilk hareket, ilk neden ve teleolojik argümanın düzen kısmı oluşturmaktadır. Descartes her ne kadar kozmosdan Tanrı'ya geçiş yapsa da onun ontolojik argümanı merkeze aldığı açıktır. Çünkü kozmolojik temellendirmelerinde dahi yeri geldiğinde çözümü zihninde kurguladığı bir Tanrı düşüncesine bağlamaktadır. Bu sebeple Tanrı var olmak için başkasına ihtiyaç duymayan ve bu özelliğinden dolayı da tüm var olanların nedenidir. ${ }^{51}$ Buradan hareketle ister ontolojinin mükemmellik algısından isterse kozmolojiden hareket edilsin Tanrı'da zat ve mahiyet aynıdır bu sebeple de Tanrı'nın bir cismi yoktur. ${ }^{52}$ Cisminin olmayışı ise onun mükemmelliğinin bir göstergesidir. Çünkü

\footnotetext{
${ }^{50}$ Descartes, Meditations, s. 38-39.

51 Descartes, Principle of Philosophy, s. 210.

52 Descartes, a.g.e., s. 200.
} 
cismin özünü uzam oluşturur ve bu da cismin parçalardan oluştuğunu gösterir. Oysa parçalara bölünme bir eksikliktir. ${ }^{53}$ Bu sebeple Tanrı basittir.

Descartes'ın bu yaklaşımı Tanrı soruşturmalarına dair yeterli bir açıklama değildir. Aranan cevap Descartes'ın nasıl bir Tanrı tasavvurunda bulunduğudur. Filozofun kendisi de bu sorunun farkındadır. Bu sebeple Tanrı imajının nasıllığı konusunda tartışmalarda bulunur. Descartes bu sorunu iki şekilde ele alır. Birincisi, Tanrı düşüncesinin örneğin Zümrüd-ü Anka kuşu gibi hayali bir varlıktan farkının olup olmadığını ayırmaya çalışır. İkincisi ise doğal nesnelerden hareketle tasavvur edilebilecek Tanrı tasavvurlarınin imkanidır.

Birinci problem ile ilgili olarak Descartes Tanr'nın imajinatif ya da mitolojik varlıklar olan Şimer ${ }^{54}$ veya Hippogriffe' den ${ }^{55}$ bir fark1nın olup olmadığının nasıl ayırabileceğini düşünür. Descartes bu sorunu, insan zihninde ki bu kavramların epistemolojik yapısını bunların ontolojik karşılıklarına indirgeyerek ele alır. Buna göre insan düşüncesinin yaptığı işin bir faili vardır. Fakat insan bu işten edindiği düşünceye başka düşüncelerde katmaktadır. Bu sebeple de insan zihninde ki kavramların hiyerarşik bir yapısı bulunur. Bu hiyerarşik yapı fikirler, irade veya teessürler ve hükümler olmak üzere üç kısımdan oluşmaktadır.

Fikirler, tek başlarına ele alındıklarında doğru şeylerdir. Fakat şeylerle ilişkilendirildikleri zaman yanlış çıkarımlara neden olabilirler. İster keçiyi isterse Şimer'i tahayyül edin; birini tahayyül etmeniz diğerini tahayyül etmenizden daha doğru değildir. Fikirler başka şeylerle ilişkilendirildikleri zaman bizi makul olmayan sonuçlara sevk edebilir.

İrade ve teessürler ise kendilerinde bir yanlışın olmasından korkmayacağımız şeylerdir. Mevcut olamayan şeyleri arzu etseniz de arzu edilenin doğruluğu ya da yanlışlığı gibi bir sorun yoktur. Arzu edilenin doğru ve yanlış olabileceğine dair bir ölçütün olmaması bir sorundur. Çünkü bizi yanıltabilir.

Hükümler ise, bizi yanıltmayan ve üzerinde durmamız gereken bir aşamadır. Çünkü insan, kendi de olan fikirlerin kendisi dışında

\footnotetext{
${ }^{53}$ Descartes, a.g.e., s. 201.

54 Aslan başlı, kedi vücutlu ve ejderha kuyruklu mitolojik bir varlıktır.

55 At vücutlu, akbaba başlı ve kanatlı efsanevi bir varlıktır
} 
olan şeylere benzediklerine hükmetmez. Bu sebeple de hükümler, dışardaki bir şey ile kıyaslanmadığı için fikirlerden dolayısıyla da yanlışlardan uzaktırlar. ${ }^{56}$

Fikirlerin bir kısmı insana doğuştan, bir kısmı dışardan gelirken, diğer bir kısmını ise insanın kendisi oluşturur. İnsan, bunların nereden geldiğini ayırabilecek bir meleke ve güce sahiptir. Örneğin ses, 1şık, sıcaklık gibi şeylerin dişardan geldiğini ve bunların birer gerçeklik olduğunu biliriz. Bu sebeple Hippogiffe ve Şimer gibi şeyler insan zihninin icat ve uydurmalarıdır. Bunu insanın kendisi idrak edebilir. ${ }^{57}$ Descartes'ın burada yeni bir sorunla yüzleşmesi gerekmektedir. Peki, bu düşünceler insan bilmese de doğuştan verilmiş ise bunların dışsal mı yoksa içsel mi olduklarını nasıl ayırt edecektir. Descartes'a göre bunların iki sebebi vardır. Birincisi, bizim bazı şeyleri tabiat tarafından bilmemizdir. Genel olarak Descartes bilgisinin kesinliğini akılla inşa ederken bu aşamada tabiatı bir referans alması şaşırtıcı olabilir. Fakat Descartes tabiat ile doğruyu bize öğreten nesneler dünyasını değil sadece insanı bir şeye inanmaya sürükleyen temayülü kast etmektedir. ${ }^{58}$ İkincisi ise, bu fikirlerin asla irademize bağlı olmadıklarını insanın kendisinin tecrübe etmesidir. Çünkü insan istese de istemese de bu fikirler kendi zihnine gelmektedir. ${ }^{59}$

Son tahlilde Descartes'a göre Tanrı'yı mitolojik veya hayali diğer varlıklardan ayıran objektif kriterler vardır. Bu kriterlerin bir kısmı kozmik temelli iken diğerleri salt rasyoneldir. Bu sebeple Tanrı'yı Şimer gibi düşünmek ve varsaymak tamamen insan zihninin icat ettiği bir uydurmadır.

Problemin ikinci boyutunu oluşturan doğal nesnelerden hareketle tasavvur edilebilecek Tanrı tasavvurlarının imkânı da filozofun tartıştığ1 konulardan biridir. Descartes'a göre insanların Tanrı'nın imajı ve doğası konusunda farklı tasavvurları olabilir. Örneğin bazıları Tanrı'yı cisimli ve cansız şeylere benzetirken bazıları da hayvanlara ve bizim gibi insanlara benzetmektedir. Descartes'a göre tüm bu düşünceler yanlıştır. Çünkü bir insan maddi cisimleri, hayvanlar ve insanları gözlemlediğinde bu varlıkların ve düşüncelerin Tanrı ile maddi şeylerin terkibinden meydana geldiklerini an-

\footnotetext{
56 Descartes, Meditations, s. 25-26.

57 Descartes, a.g.e., s. 26.

58 Descartes, a.g.e., s. 27.

${ }^{59}$ Descartes, a.g.e., s. 26.
} 
layacaktır. Descartes bu kategoriyi zihinsel bir üst kategoriye taş1yarak kavramsal olarak bu terkibin dışında hiçbir varlığında olmadığını belirtir. Maddi ve cisimli şeylerin fikirleri ile ilgili olarak, ne kadar büyük ve mükemmel olurlarsa olsunlar, bunları insanın üretmeyeceğini ve insanın açık seçik idrak ettiği pek az şeyin olduğunu belirtir. ${ }^{60}$

\section{Tanri'nın Sıfatları}

Tanrı'nın sıfatları konusu Descartes'ın doğrudan ele almadığı bir konudur. Çünkü onun asıl problemi düşünceyi ve doğayı güvence altına almak için Tanrı'nın varlığının ispatıdır. Sıfatlar konusunda ise filozof, mükemmeliyetçi Tanrı tasavvurunu kabul ettiği için dolayısıyla teizmin kabul ettiği sıfatları savunur. Fakat Descartes, kendisini Antik Çağdan kopuş olarak gördüğü için yeri geldiğin de klasik teizmden ayrılır. Descartes'ın ayrıldığı noktalar ise Tanrı-ve doğa ilişkileri noktasındadır. Bu sebeple Tanrı-doğa düalizmi kartezyen felsefenin önemli sacayaklarından biridir.

Descartes, Paris İlahiyat fakültesinde yaptığı konuşmada Tanrı ve ruh konusunun ilahiyatın değil felsefenin getirdiği delillerle ispatlanmasının daha doğru ve gerekli olduğunu ifade etmiştir. ${ }^{61} \mathrm{Bu}$ tutumu onun hem yönteminin bir gereği hem de kilisenin öngördügü bazı düşüncelere katılmadığının da bir işaretidir. Çünkü Descartes, rasyonel bir yöntemi savunurken kilise geleneksel nakil yöntemine sadık kalmış ve bu sebeple de dogmatikleşmiştir. Bu sebeple Descartes ve kiliseyi bir birinden ayıran en önemli ayrım yöntemdir. Tüm rasyonelliğine ve skolastik dönemden koptuğunu iddia etmesine rağmen Descartes her zaman kiliseye sadakatini sunar. Örneğin rasyonel olmamasına rağmen Descartes'ın kendi ifadesiyle düşüncemizi aşmasına rağmen inkarnasyon ve teslisin gerçekliğine inanmanın gerekliliğini savunur. ${ }^{62}$ Descartes'ın bu düşüncesi genel metodu ile uyuşmamaktadır. Filozofun bu yaklaşımını belki tarihsel ve konjonktürel olarak okuyabiliriz. Çünkü kendisinden önceki birçok düşünür ve bilim insanı aynı zamanda siyasal bir erk olan kilise ile çatıştığ 1 için şiddetli bir şekilde cezalandırılmışlardı. Descartes'ın böyle bir kaygısının ve korkusunun olduğunu bilmiyoruz.

\footnotetext{
${ }^{60}$ Descartes, a.g.e., s. 29.

61 Descartes, a.g.e., s. 3.

62 Descartes, Principle of Philosophy, s. 201.
} 
Descartes'a göre Tanrı'nın sıfatlarını ispatlamanın yolu doğadan geçmektedir. Buna göre Tanrı, mutlak, ezeli, ebedi, her şeye gücü yeten, her şeyi bilen, tüm varlıkların yaratanı, her türlü iyi ve doğrunun kaynağı, tüm yetkinliklere sahip ancak kendisinde hiçbir eksikliğin bulunmadığ 1 bir varlıktır. ${ }^{63} \mathrm{O}$ son derece tam ve yetkin olduğu için bildiği veya yaptığı hiçbir şeyde yanlışlık yoktur. Bu sebeple hiçbir yanlışın illeti değildir. ${ }^{64}$ Descartes'ın bu yaklaşımı ister istemez kötülük probleminin oluşturduğu sorunlarla yüzleşmek zorundadır. Araştırmamızın konusu olmadığı için bu tartışmalara girmeyeceğiz. ${ }^{65}$

Her ne kadar duyulara sahip olmak insanın bilgi edinmesi için yararlı şeyler gibi görünse de duyular dış dünyaya bağlılı̆̆1 gösteren şeylerdir. Bu da insan için bir eksikliktir. Bu sebeple Tanrı'nın bilmek ve işitmek gibi eylemler için duyulara da ihtiyacı yoktur. ${ }^{66}$

Sonuç olarak Descartes, teistik klasik Tanrı anlayışını savunmaktadır. Ancak Tanrı ve doğa ilişkilerini deistik bir tarzda açıklamaktadır. Buna göre Tanrı her açıdan mükemmel bir varlıktır ancak alemden ayrı bir tözdür. Descartes'ın birbiriyle çelişen bazı görüşlerine yeri geldikçe dikkat çekmeye çalıştık. Teistik tanrısal sıfatlar ve deistik evren tasavvurunda da filozof çelişkili bir durum yaşamaktadır. Çünkü her açıdan mükemmel bir varlık olan Tanrı'nın evrene müdahil olmaması ya da olamaması onun için bir eksikliktir. Burada Tanrı'nın dışsal müdahaleye gerek duymadan işlevselliğini devam ettirecek mükemmellikte bir evren yarattığ ${ }_{1}$ şeklinde bir itiraz edilebilir. Ancak açıkça görülen o dur Tanrı'nın faaliyet alanı sınırlandırılmıştır.

\section{Sonuç}

Şüphesiz Descartes, Tanrı'yı zihinden hareketle ispatlamanın bir ifadesi olan ontolojik delilin inşacılarından olmakla birlikte bu delil ile özdeşleştirilmiş bir filozoftur. Bu yaklaşım filozof için doğru bir tanımlamadır. Biz bu çalışmada Descartes kozmolojisinden hareketle Tanrı'nın ispatını ele aldık. Descartes her ne kadar bir ontolojik delil savunucusu olsa felsefesinde kozmolojik argümana da yer vermektedir. Fakat açıkça belirtmek gerekir ki her ne kadar kozmolojik

\footnotetext{
63 Descartes, Meditations, s. 31.

64 Descartes, a.g.e., s. 42.

${ }^{65}$ Konuyla ilgili olarak bkz. İlyas Altuner, “Descartes Felsefesinde Tanrı-Varlık İlişkisi” I ̆ğdır Üniversitesi Sosyal Bilimler Dergisi, Sy. 2, Ekim 2012, s. 43.

${ }^{66}$ Descartes, Felsefenin Ilkeleri, s. 42.
} 
argümanı bir delillendirme türü olarak kullansa da bunu nihai olarak ontolojik delile bağlamaktadır. Bunun birkaç nedeni olabilir. Birincisi, Descartes duyulara fazla güvenmemektedir. Oysa kozmolojik argümanın temelini aslında duyular oluşturur. İkincisi, filozof skolastik felsefeden tam olarak kopamamıştır. Bu sebeple her ne kadar aklı merkeze alsa da birçok konuda duyular ve akıl arasında sıkışıyor görünmektedir. Üçüncüsü, Descartes'ın yaşadığı dönemde ki din ve bilim etkileşimidir. Örneğin Descartes'ın güneş merkezli evreni kabul ettiği ancak bunu açıklamakta tereddütlerinin olduğu bilinmektedir. Bu sebeple filozof aklı merkeze alan bir felsefe inşa etmiş ancak duyuları merkeze alan bilimden de uzak kalamamıştır.

Descartes felsefesinde ki kozmolojik argümanlar salt duyu ve gözlem verilerine dayanmamaktadır. Descartes duyu verilerinden rasyonel ve sezgisel çıkarımlar yaparak sonucu yine şüphenin ve aklın güvencesine bağlamaktadır. Bu sebeple Descartes düşüncesinde ki bu delillendirmeyi salt kozmolojik argüman olarak değil de ontolojik kozmolojik argüman olarak ifade etmek daha yerinde bir tespit olacaktır.

\section{Kaynakça}

Altuner, İlyas (2012). "Descartes Felsefesinde Tanrı-Varlık İlişkisi” Iğdır Üniversitesi Sosyal Bilimler Dergisi, Sy. 2, Ekim, s. 31-48.

Aristoteles (1996). Metafizik, çev. Ahmet Arslan, İstanbul: Sosyal yayınları.

Aristoteles (2001). Fizik, Çev. Saffet Babür, İstanbul: YKY yay.

Cevizci, Ahmet (2007). On Yedinci Yüzyll Felsefesi Tarihi, Bursa: ASA yay.

Dağ, Mehmet (1978). “Ontolojik Delil ve Çıkmazları” Ankara Üniversitesi İlahiyat Fakültesi Dergisi, c. XXII, s. 287-318.

Descartes, René (19585). Principle of Philosophy, Philosophical Writings of Descartes, Trans. John Cottingham, Robert Stoothoff, Dugald Murdoch, Vol. 1, Cambridge University Press.

Descartes, René (1984). Metot Üzerine Konuşma, Çev. K. Kahir Sel, İstanbul: Sosyal yay., 2. Bsk.

Descartes, René (1985). Rules for the Direction of the Mind, Philosophical Writings of Descartes, Trans. John Cottingham, Robert Stoothoff, Dugald Murdoch, Vol. 1, Cambridge University Press.

Descartes, René (1995). Meditations on First Philosophy, Philosophical Writings of Descartes, Trans. John Cottingham, Robert Stoothoff, Dugald Murdoch, Vol. II, Cambridge University Press.

Descartes, René (1995). The Search Truth by Means of The Naturel Light, Philosophical Writings of Descartes, Trans. John Cottingham, Robert Stoothoff, Dugald Murdoch, Vol. II, Cambridge University Press. 
Descartes Felsefesinde Kozmolojik Argüman Soruşturması

Hatfield, Garry (2003). Descartes And Meditations, Routledge: Philosophy Guide Books.

Hume, David (1895). An Enquiry Concerning the Human Understanding, Oxford: Clarendon Press.

Murphy, Nancey (2013). “Bilim, İlahi ve Zeki Tasarım Akımı: Teistik Evrimciliğin Bir Savunusu", Evrim ve Tasarım (Gelen-Eksel ve Çă̆daş Metinler Seçkisi), Der. Recep Alpyağıl, İstanbul: İz yay.

Öktem, Ülker (2000) "Descartes Epistemolojisinde Tanrı'nın Yeri" AÜDTCF, 40 (3-4), s. 29-35.

Özden, H. Ömer (2000). İbn Sina-Descartes Metafizik Bir Karşılaştırma, İstanbul: Dergâh yay.

Wang, Torrey (2012). "Descartes' Three Proofs of God's Existence", Intro to Philosophy, Spring, s. 1-4.

Zeller, Eduard (2001). Grek Felsefesi Tarihi, Çev. Ahmet Aydoğan, İstanbul: İz yay. 


\section{MILEL VE NIHAL}

inanç, kültür ve mitoloji araştırmaları dergisi

Cilt/Volume: 11 Sayı/Number: 2 Temmuz - Aralık / July - December 2014

ISSN: 1304-5482

Bu dergi uluslararası EBSCO HOST Research Databases veri indeksi ve

TÜBITAK-ULAKBİM Sosyal ve Beşeri Bilimler Veri Tabanı tarafından taranmaktadır.

\section{Sahibi / Owner}

Milel ve Nihal Eğitim, Kültür ve Düşünce Platformu Derneği adına Şinasi Gündüz

$$
\begin{aligned}
& \text { Yazı İşleri Sorumlusu / Legal Representative } \\
& \text { Yasin Aktay }
\end{aligned}
$$

Editör / Editor

Şinasi Gündüz

Editör Yrd. / Co-Editor

Cengiz Batuk

Hakan Olgun

\section{Yayın Kurulu/ Editorial Board*}

Alpaslan Açıkgenç, Ayaz Akkoyun, Yasin Aktay, Mahmut Aydın,

Cengiz Batuk, Şinasi Gündüz, İbrahim Kayan, Hakan Olgun, Necdet Subaşı,

\section{Burhanettin Tatar}

\section{Danışma Kurulu/Advisory Board*}

Baki Adam (Prof. Dr., AÜ); Mohd. Mumtaz Ali (Prof. International Islamic U. Malezya); Adnan Aslan (Prof.Dr., Süleyman Şah Ü.); Kemal Ataman (Doç.Dr., Uludağ Ü.); Mehmet Akif Aydın (Prof. Dr., Marmara Ü.); Yılmaz Can (Prof. Dr., OMÜ); Ahmet Çakır (Doç. Dr., OMÜ); Mehmet Çelik

(Prof. Dr., Celal Bayar Ü.); Waleck S. Dalpour (Prof. University of Maine at Farmington); İsmail

Engin (Dr., Berlin); Cemalettin Erdemci (Prof.Dr. YYÜ); Tahsin Görgün (Prof.Dr., 29

Mayıs Ü.) Ahmet Güç (Prof.Dr., Uludağ Ü.); Recep Gün (Doç. Dr., OMÜ); Ö. Faruk Harman

(Prof.Dr., Mar.Ü.); Erica C.D. Hunter (Dr., Cambridge U.); Mehmet Katar (Prof. Dr., A.Ü.);

Mahmut Kaya (Prof. Dr., İ.Ü.); Sadık Kılıç (Prof.Dr., Atatürk Ü.); Şevket Kotan (Y.Doç.Dr., İ.Ü.); İlhan Kutluer (Prof.Dr., Mar. Ü.); George F. McLean (Prof. Catholic Univ., Washington DC); Ahmet Yaşar Ocak (Prof. Dr., Hacettepe Ü.); Jon Oplinger (Prof. University of Maine at Farmington); Ömer Özsoy (Prof.Dr., Frankfurt U.); Roselie Helena de Souza Pereira (Mestre em

Filofia-USP; UNICAMP Brasil); Ekrem Sarıkçıŏlu (Prof.Dr., SDÜ); Hüseyin Sarıoğlu (Prof.Dr.,

İÜ); Bobby S. Sayyid (Dr. Leeds U.); Mustafa Sinanoğlu (Prof.Dr., 29 Mayıs Ü.); Mahfuz Söylemez

(Prof.Dr. IÜ); Necdet Subaşı (Y.Doç.Dr., DİB); Bülent Şenay (Prof.Dr., UÜ); İsmail Taşpınar

(Prof.Dr. Mar.Ü.); C. Sadık Yaran (Prof.Dr., OMÜ); Ali Murat Yel (Prof.Dr., Fatih Ü.); Hüseyin Yılmaz (Doç.Dr., YYÜ); Ali İhsan Yitik (Prof. Dr., DEÜ)

* Soyadına göre alfabetik sıra / In alphabetical order

\section{Kapak ve Sayfa Tasarımı / Cover \& Page Design} İnan Avc1

Baskı / Publication

Ladin Ofset - İstanbul, Haziran 2015

2.Mat. Sit. 3 NB 15 Topkapi İstanbul / İsmail Tüz 02125012418

Yönetim Yeri / Administration Place

Milel ve Nihal Eğitim, Kültür ve Düşünce Platformu Derneği

Fevzipaşa Cad. Şehit Mehmet Sarper Alus Sok. No: 5, K.: 3, Tel: (0212) 5339731 Fatih/İstanbul www.milelvenihal.org e-posta: dergi@milelvenihal.org

Milel ve Nihal yılda iki sayı olarak altı ayda bir yayımlanan uluslararası hakemli bir dergidir. Milel ve Nihal' de yayımlanan yazıların bilimsel ve hukuki sorumluluğu yazarlarına aittir. Yayım dili Türkçe ve İngilizce'dir. Yayımlanan yazıların bütün yayın hakları Milel ve Nihal'e ait olup, yayıncının izni olmadan kısmen veya tamamen basılamaz, çoğaltılamaz ve elektronik ortama taşınamaz. Yazıların yayımlanıp yayımlanmamasından yayin kurulu sorumludur. 


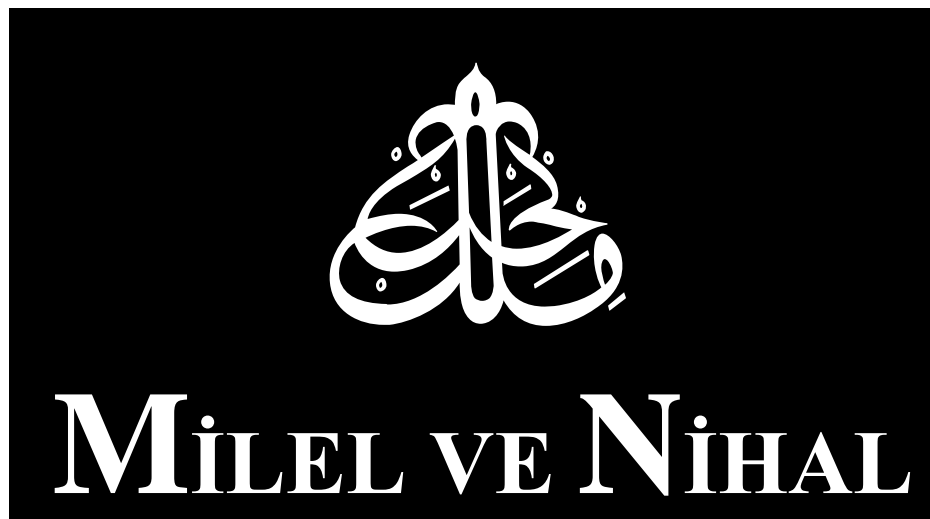

inanç, kültür ve mitoloji araştırmaları derogisi

ISSN: 1304-5482

Cilt/Volume: 11 Sayı/Number: 2

Temmuz - Aralık / J uly - December 2014 


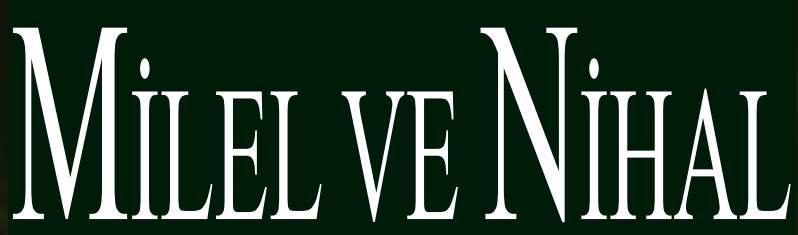

inanç, kültür ve mitoloji araştırmaları dergisi

ISSN 1304-5482

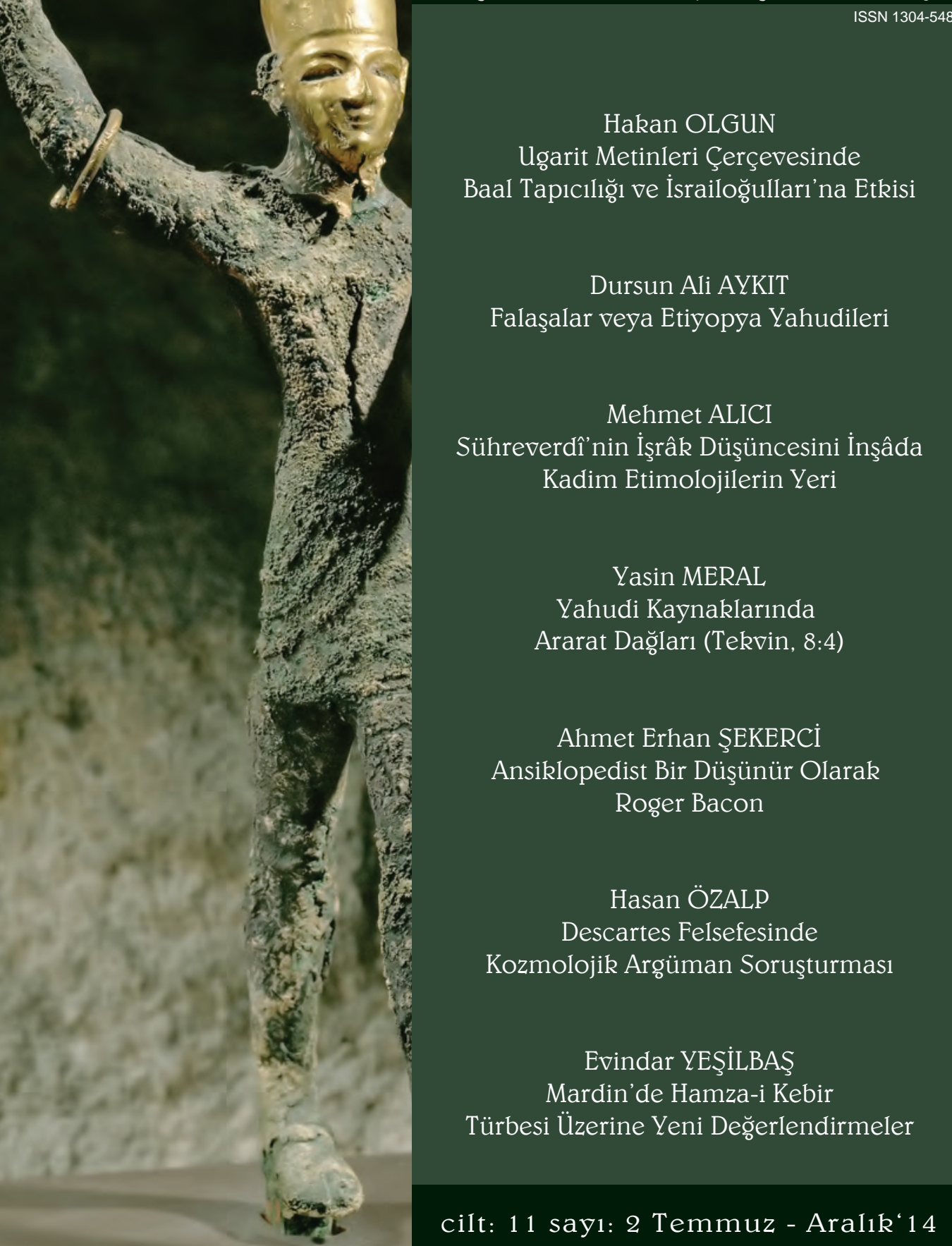

